\title{
WINDROW COMPOSTING OF WASTE SLUDGE AND EFFECTS COMPOSTS ON PLANT GROWTH AND SOIL CHARACTERISTICS
}

\author{
YILDIZ S., ${ }^{1 *}$ \\ DEĞIRMENCI M. ${ }^{1}$ \\ KAPLAN M. ${ }^{2}$
}

Received: $28 / 12 / 2015$

Accepted: $11 / 04 / 2016$

Available online: $25 / 07 / 2016$

\author{
${ }^{1}$ Cumhuriyet University, Engineering Faculty \\ Department of Environmental Engineering, 58140, Sivas, Turkey \\ ${ }^{2}$ Erciyes University Agricultural Faculty \\ Department of Field Crops, 38038, Kayseri, Turkey
}

*to whom all correspondence should be addressed: e-mail: sayiteryildiz@gmail.com

\section{ABSTRACT}

Sludge is the ultimate by product of all traditional and conventional wastewater treatment processes. Conversion of the treatment sludge into new products is a significant disposal alternative for these wastes. In this study, branches, leaves and the organic and inorganic trash coming out from the aerated sand trap unit have all been mixed up with determined mixing ratios and composting has been realised by windrowcomposting technique. The present study was conducted to investigate the effects of 4 different treatment sludge composts and chemical fertilizer on soil characteristics and plant (oat and grass) yields. Experiments were conducted in randomized black design with 3 replications in a plastic high-tunnel greenhouse. The sludge composts of sample1 (S1) and sample2 (S2) were applied at rates of $4 \mathrm{t} / \mathrm{da}$ and $6 \mathrm{t} / \mathrm{da}$. Chemical fertilizer was applied in the form of $\mathrm{N}_{8} \mathrm{P}_{6}$. Grass was sown in a rate of $20 \mathrm{gr} \mathrm{m}^{-2}$. Oat was sown in pots at a rate of 60 seeds per pot and then thinned to have 40 plants in each pot. Sludge composts in grass and oat culture significantly improved soil characteristics and increased the plant yields. It was concluded that sludge composts could be used as an alternative soil amendment.

Keywords: Waste sludge, composting, soil yield, grass yield, soil amendment

\section{Introduction}

Sludge composting has become an increasingly significant feasible strategy for this wastewater waste (El Fels, 2014). Due to the sewage sludge characteristics, high water content, organic matter content is not high, small porosity, high viscosity. Therefore using sewage sludge as basic materials composting, usually with leaves, sawdust, wood, straw, compost improvement (Chen, 2012). During composting, organic matter is transformed into a humus-rich product by the action of microorganisms and their enzymes (Khalil et al., 2011).

In general, amount of waste sludge will increase in near future. Therefore, it is beneficial to investigate the factors effecting composting process and compost optimization and to investigate alternative uses of composted material as a fertilizer or soil amendment. Beside this, widespread of composting will allow better control of the processes, let more reliable compost quality and minimize environmental risks (Khalil et al., 2011).

Different bulking agents have been used at waste sludge composting operational tests. Many researchers have reported the effectualness of adding bulking agents such as lignocellulosic waste (Fels et al., 2016a), date palm (Fels et al., 2016b), recyclable plastic (Zhou et al., 2014), palm oil (Tweib et al., 2014), tree bark,

Yildiz S., Değirmenci M. and Kaplan M. (2016), Windrow composting of waste sludge and effects composts on plant growth and soil characteristics, Global NEST Journal, 18(3), 652-664. 
sawdust, peat (Zuokaite and Zigmontienè, 2013), straw (Kulikowska and Klimiuk, 2011; Bousselhaj et al., 2004; Cartney, 2004; Gouxue et al., 2001), wood chips (Eftoda and Mc Cartney, 2004), waste paper (Tang and Katayama, 2005), grass (Kulikowska and Klimiuk, 2011) and compost in improving the composting process.

However, several researchers investigated the effects of sludge and chemical fertilizer treatments on soil physical and chemical characteristics, plant yield and quality parameters. Larson et al., (1974), indicated that sludge was able to meet nitrogen, phosphorus and micronutrient needs of agricultural produce and may reliably be used over agricultural fields with proper implementations. Aggelides and Londra, (2000), determined the effects of compost composed of municipal waste (62\%), treatment sludge (21\%) and wood shavings (21\%) on physical characteristics of clay-loam soil. Hernandez et al., (2002), investigated nitrogen mineralization of two different waste treatment sludge produced under aerobic and anaerobic conditions in clay and sandy soils and observed almost twice as much nitrogen mineralization in sandy soil without any leaching.

Antolin et al., (2005), compared inorganic fertilizer, single 15 ton ha ${ }^{-1}$ sludge and annual 15 ton ha ${ }^{-1}$ sludge treatments with control treatment with regard to their impacts on barley yield for three years. Pascual et al., (2005) carried out a research under dry and irrigated greenhouse conditions with different doses of domestic waste treatment sludge and mineral fertilizers and reported that sludge treatments under irrigated conditions increased available $\mathrm{NO}_{3}{ }^{-}, \mathrm{NH}_{4}{ }^{+}, \mathrm{P}$ and electrical conductivity.

In a sludge treatment study, Su et al., (2005) reported Cu content of alfalfa as between $25.9-29.5 \mathrm{mg} \mathrm{kg}^{-1}, \mathrm{Ni}$ content as between 2.11-4.60 mg kg${ }^{-1}$, Zn content as between $61.4-84.3 \mathrm{mg} \mathrm{kg}^{-1}$, Fe content as between 138.5-204.7 mg kg-1 and Mn content as between 137.6-293.5 mg kg-1. Wei and Liu, (2005) carried out a 3years study in China to investigate the effects of sludge plus wood shaving compost and mineral fertilizer treatments on germination power of rapeseeds, yield of zucchini and barley and heavy metal contents of soil and plants.

Toribio and Romanya, (2006), in Romania investigated the relationships between soil characteristics and $\mathrm{Cu}$, $\mathrm{Zn}, \mathrm{Ni}$ and organic matter leaching through forest soils under three different sludge doses in Mediterranean climate zone. Tejada and Gonzalez, (2007), applied four different organic wastes in Spain (cotton, olive, treatment sludge, domestic waste) at an annual rate of 10 tons to investigate the effects of such waste materials on soil structure and soil loss under rainfall simulations. Casado Vela et al., (2007), determined the effects of 3, 6 and $9 \mathrm{~kg} \mathrm{~m}^{-2}$ sludge doses on physico-chemical characteristics of soil under field and greenhouse conditions. Cheng et al., (2007), investigated the effects of different doses of sludge plus soil mixtures on turf grass growth and soil characteristics. Toumpeli et al., (2013), investigated the effects of different composts on physico-chemical characteristics of soils and yields of tomato plants. Weber et al., (2014), used domestic solid waste sludge and investigated possible improvement of plant nitrogen uptake in sandy soils. Neugschwandtner and Kaul, (2014), carried out a research to investigate the effects of different sowing norms and nitrogenous fertilizers on oat and pee yields.

The objectives of this study were to: (1) compost of waste sludge, branches, leaves and the organic and inorganic trash coming out from the aerated sand trap unit which have been mixed up with determined mixing ratios and composting has been realised by windrow-composting technique; and (2) investigate the effects of these 4 different treatment sludge composts and a chemical fertilizer which applied in two different doses effects of treatments on soil characteristics and plant yields.

Windrows have been formed with tree branches and leaves which have been incorporated into the waste sludge with predetermined mixture ratios of organic and inorganic wastes coming out of the ventilated sand catcher unit of the domestic waste water treatment plant. Input materials of the windrow to be formed and mixture ratios of these input materials differ according to the planned product which we desired to obtain at the end of the research study. However, in this study, different treatment sludge composts and a inorganic fertilizer were applied in two different doses and effects of treatments on soil characteristics and plant yields were investigated. The composts and fertilizer were separately applied to oat and grass and the effects on soil and plant yields were compared. 


\section{Materials and methods}

\subsection{Composting mixtures and process}

The sludge of domestic wastewater treatment facility of Sivas Province of Turkey was composted with leaves, branches, organic and inorganic wastes of aerated sand filter unit of the facility by using windrow composting technique. Dimensions of each windrow one by one have been determined separately. Length, height and width of the windrow 1 (W1) has been selected as $3 \mathrm{~m}, 1,5 \mathrm{~m}$, and 2,5 m respectively. Length, height and width of the windrow 2 (W2), windrow 3 (W3) and windrow 4 (W4) have been selected as $4 \mathrm{~m}, 1,5 \mathrm{~m}$ and 2,5 $\mathrm{m}$ respectively. Total volume of the $\mathrm{W} 1$ is $11,25 \mathrm{~m} 3$ according to these dimensions and total volume of $\mathrm{W} 2$, W3 and W4 is $15 \mathrm{~m}^{3}$. Input amounts in accordance with the unit volumes at Table 1 have each been calculated one by one. The windrow compositions, mixture rates and amounts are presented in Table 1 . After the end of the 24 weeks samples have been taken from the three windrows formed within the context of the research study and analyses of the samples have been carried out. However volumes of each windrow have been measured again after the 24 weeks period of time. Howmuch each windrow degreased in volume has been determined by comparing the initial volumes and the volumes after formation. Initial volumes of each product and the volumes after the formation and percentages of decrements have been given at Table 2 .

Table 1. Mixture ratios for each windrow

\begin{tabular}{|c|c|c|c|c|c|c|c|c|}
\hline \multirow[t]{2}{*}{ Input material } & \multicolumn{2}{|c|}{$\begin{array}{c}\text { Windrow } 1 \\
\text { (W1) }\end{array}$} & \multicolumn{2}{|c|}{$\begin{array}{c}\text { Windrow } 2 \\
\text { (W2) }\end{array}$} & \multicolumn{2}{|c|}{$\begin{array}{c}\text { Windrow } 3 \\
\text { (W3) }\end{array}$} & \multicolumn{2}{|c|}{$\begin{array}{c}\text { Windrow } 4 \\
\text { (W4) }\end{array}$} \\
\hline & $\begin{array}{c}\text { volume/ } \\
\text { unit }\end{array}$ & $\mathrm{m}^{3}$ & $\begin{array}{c}\text { volume/ } \\
\text { unit }\end{array}$ & $\mathrm{m}^{3}$ & $\begin{array}{c}\text { volume/ } \\
\text { unit }\end{array}$ & $\mathrm{m}^{3}$ & $\begin{array}{c}\text { volume/ } \\
\text { unit }\end{array}$ & $\mathrm{m}^{3}$ \\
\hline Waste sludge & 0,75 & 2.81 & 0,5 & 2,5 & 1,0 & 2 & 0,5 & 0,42 \\
\hline Leaves & 1,0 & 3,75 & 1,0 & 5 & 1,0 & 2 & 1,0 & 0,83 \\
\hline Branches & 1,0 & 3,75 & 1,0 & 5 & 1,0 & 2 & 1,0 & 0,83 \\
\hline $\begin{array}{l}\text { Organic trash coming } \\
\text { out of the aerated } \\
\text { sand trap unit }\end{array}$ & 0,25 & 0,94 & - & - & - & - & - & - \\
\hline $\begin{array}{l}\text { Inorganic trash } \\
\text { coming out of the } \\
\text { aerated sand trap unit }\end{array}$ & - & - & 0,5 & 2,5 & - & - & 0,5 & 0,42 \\
\hline Soil & - & - & - & - & 4,5 & 9 & 15 & 12,5 \\
\hline
\end{tabular}

Table 2. Volumetric variation occurring at each windrow

\begin{tabular}{cccc}
\hline & Initial volume $\left(\mathrm{m}^{3}\right)$ & Final volume $\left(\mathrm{m}^{3}\right)$ & Rate of change \% \\
\hline W1 & 11,25 & 3,5 & $\% 69$ \\
\hline W2 & 15 & 4,8 & $\% 68$ \\
\hline W3 & 15 & 7 & $\% 53$ \\
\hline W4 & 15 & 11 & $\% 26$ \\
\hline
\end{tabular}

\subsection{Cultivation experiment design}

Different windrow composts of wastewater treatment sludge and a chemical fertilizer were used. Experiments were conducted in randomized block design with 4 replications and carried out in a high-tunnel plastic greenhouse. Experiments were conducted in 33 It pots. Sludge composts of S1 (W1) and S2 (W2) were applied at the rates of $0.4 \mathrm{t} \mathrm{ha}^{-1}$ and $0.6 \mathrm{t} \mathrm{ha}^{-1}$. Since S3 (W3) and S4 (W4) composts have soil characteristics (Table 3). It was used without mixing with the natural soil. The chemical fertilizer (S5) was applied in the form of $\mathrm{N}_{8} \mathrm{P}_{6}$. Sowing was performed following the saturation of the pots. Oat was sown at a rate of 60 seeds per pot and grass was sown at a rate of $20 \mathrm{gr} \mathrm{m}^{-2}$ (Zengin and Özbahçe, 2011). Stalk lengths of harvested oat plants were measured. Then, stalk and kernels were separated and weighted separately. Chemical analyses were performed over oat stalks and kernels and grasses. Soil samples were taken from the pots and analyses were performed over these soil samples. 


\subsection{Soil chemical analyses}

Soil $\mathrm{pH}$ values were measured potentiometrically with a glass-electrode $\mathrm{pH}$ meter from 1/2.5 soil-water mixture (Page et al., 1982). Organic matter content was determined through wet ashing method in accordance with Nelson and Sommers, (1982). Nitrogen content of soil samples were determined by using micro-kjheldahl method after wet ashing in salicylic acid + sulphuric acid + salt mixture (Bremner and Mulvaney 1982). Exchangeable cations were determined from $1 \mathrm{~N} \mathrm{NH4OAc} \mathrm{extract} \mathrm{with} \mathrm{a} \mathrm{flame} \mathrm{photometer}$ for $\mathrm{Na}$ and $\mathrm{K}$; and $\mathrm{Ca}+\mathrm{Mg}$ and $\mathrm{Ca}$ were calculated titremetrically with EDTA. Since the soluble $\mathrm{CaCO}_{3}$ contents of soil are high (3.73-12.27\%), $\mathrm{Ca}+\mathrm{Mg}$ and Ca values were also very high. As recommended by Kaçar, (2009), " $1 \mathrm{~N} \mathrm{NaOAc} \mathrm{pH=8.2} \mathrm{extract} \mathrm{solution} \mathrm{yields} \mathrm{better} \mathrm{results} \mathrm{than} \mathrm{neutral} 1 \mathrm{~N} \mathrm{NH4OAc} \mathrm{extract} \mathrm{solution} \mathrm{in} \mathrm{soils}$ with independent $\mathrm{CaCO}_{3}$ contents over 5\% (Bower et al., 1952)", $\mathrm{Ca}$ and $\mathrm{Mg}$ values were determined from $1 \mathrm{~N} \mathrm{NaOAc}$ extract. Exchangeable sodium percentage (ESP) was calculated from exchangeable $\mathrm{Na}$ and cation exchange capacity (CEC) values by using the equation of ESP = (Na / CEC) 100 (Bower, 1959). Soil clay, silt and sand contents were determined by hydrometer method in accordance with Gee and Bauder, (1986).

In the all materials (which used in composting) and compost production (W1-W4) the heavy metal analysis showed that the values are too small (Table 3). For this reason, it is known that heavy metal are not in the composts which used in oaats and grass experiments

\subsection{Plant analyses}

Dry hay samples were taken and made ready for analyses by grinding in a grinder with $1 \mathrm{~mm}$ sieve. Crude ash content of forage was determined by ashing the samples at $550^{\circ} \mathrm{C}$ furnace for 8 hours. Kjeldahl method was used to determine nitrogen $(\mathrm{N})$ contents of dried samples. Crude protein was calculated by using the equation Nx6.25 (AOAC 1990). Tannin was determined in accordance with Makkar et al., (1995), NDF (Van Soestve Wine, 1967) and ADF (Van Soest, 1963) were determined by using ANKOM 200 Fiber Analyzer (ANKOM Technology Corp. Fairport, NY, USA) device. Crude cellulose was also determined by using ANKOM 200 Fiber Analyzer in accordance with Van Soestve Robertson (1979).

\subsection{Statistical analysis}

Resultant data were subjected to variance analysis with SAS (SAS Inst., 1999) statistical software. Duncan test was used to test the significance of differences between the means.

\section{Results and discussion}

\subsection{Characteristic Properties of the Products Formed}

Specimens have been taken from varying depths and different points of the windrow and these specimens have been mixed and turned over and then samples have been taken from this mixed and turned over mixture as $1 \mathrm{~kg}$ in weight

As a result of the analysis four products of which the mixture ratios have been determined as planned before starting the process have been obtained (W1, W2, W3, W4). Analysis conclusions of the final products and bulking agents added into the waste sludge are seen at Table 3.

Various reactions occur during the decomposition of organic matter and synthesis of microbial cells. Several organic and inorganic acids are formed in the soil as a result of these reactions and these organic and inorganic acids affect the minerals by degrading them. During this degradation, nutrient elements of which the plants can not take benefit and are within the structure of the minerals turn into water-soluble forms of which the plants can take benefit.

Main variations occurring at inorganic matter structure of soils; (1) Phosphate compounds which are in insoluble form turn into the compound forms which can easily dissolve in water. (2) Calcium, magnesium and other slightly soluble carbonates turn into easily soluble forms (3) Potassium compounds which are in insoluble form degrade and easily soluble compounds come into existence. Thus, soil organisms enable required chemical modifications within the mineral structure of the soil just like as they do in the organic 
structure of the soil and increase the amount of nutrient elements (matters) which are obtainable from the soil and affect soil fertility positively (Brohi et al., 1997).

The process of composting might be employed as the final stage of sludge treatment. The key composting factors having an influence on the process and finished roduct include aeration, humidity, temperature, $\mathrm{pH}$ and duration of compost maturation. The quality of compost also depends on the structure and size of particles as well as the content of nitrogen, carbon, and heavy metal phosphorus and potassium. Carbon, nitrogen, phosphorus and potassium are the main substances necessary for the optimum activities of microorganisms during composting. These substances are also necessary for plants to grow and develop. Therefore, the value of compost depends on their content in it (Lazdina et al., 2007).

It is known that required nutrient elements were met by chemical fertilizers which were applied to the soil in various chemical forms for plant growing in agricultural production. Most applicated nutrient elements to the soil with chemical fertilizers are nitrogen, phosphor and potassium. These three elements as well as the elements calcium, magnesium and sulphur are used by the plants excessively and they are the nutrient elements received from the soil. Other than these elements there are other elements that the plants receive from the soil but use less compared to the other abovementioned elements like ferro, manganese, boron, molybdenum, copper, zinc, chlorine, cobalt. Macro and micro nutrient element values within the final product are fairly fine as can be seen in Table 3.

The $\mathrm{C} / \mathrm{N}$ ratio is an important parameter in composting because it provides a useful indication of the probable rate of OM decomposition. Microorganisms use about 30 parts of carbon for each part of nitrogen. Thus, an initial $\mathrm{C} / \mathrm{N}$ ratio of 20-35 would be most favourable for rapid conversion of organic wastes into compost. Sewage sludges usually have $\mathrm{C} / \mathrm{N}$ ratios of less than 15 . Although decomposition will be rapid at this ratio, nitrogen may be lost as ammonia (Willson et al., 1980). Ratio $\mathrm{C} / \mathrm{N}$ of the treated sludge used in this research study is 5.1 Ratio $\mathrm{C} / \mathrm{N}$ of the windrows $\mathrm{W} 1, \mathrm{~W} 2$ and $\mathrm{W} 3$ have been determined as $13.5,17,10.2$ respectively. These values are quite appropriate in terms of their being used in soil.

It can be seen in Table 3 that the product obtained during the study was quiet rich in terms of soil macro elements $\mathrm{Ca}, \mathrm{Mg}, \mathrm{K}, \mathrm{Na}$. Besides, a rich product has been formed in terms of both organic materials and other micro elements. Formed product is such a quality product that it can be used as a fertilizer for the improvement of the other soil types.

Compost EC is of great importance from an agricultural point of view since it can be a limiting factor of plant growth and seed germination. Santamaría-Romero and Ferrera (2001) indicated that EC higher than $8 \mathrm{dS} \mathrm{m}{ }^{-1}$ had a negative effect on soil microbial populations and on organic matter biotransformation.

\subsection{Soil Measurement after Experiment}

Following the plant harvest, soil samples were taken from the pots and relevant analyses were performed over these samples. Analyses results of soil samples are presented in Table 4. S1 and S2, obtained from treatment sludge and applied at different doses to soil, both significantly increased the phosphorus content of the soil. Increasing phosphorus contents were observed with increasing compost doses. Phosphorus content was 66.35 ppm in S1a, 83.14 ppm in S1b, 77.98 ppm in S2a and 91.87 ppm in S2b. The value was $25.10 \mathrm{ppm}$ in chemical fertilizer applied soil (S5). Effects of sludge composts on soil P contents were significantly higher than the effects of chemical fertilizer.

Significant increases were also observed in soil organic matter with the applied materials. Organic matter contents of S1 and S2 treatments were respectively observed as 1.8-2.10-2.51-3.71. Organic matter content of $\mathrm{S} 5$ treatment was observed as 0.86 . 
Table 3. Conclusions of the analysis belonging to the soilification input materials and products formed.

\begin{tabular}{|c|c|c|c|c|c|c|c|c|c|}
\hline Parameters & $\begin{array}{c}\mathrm{EC} \\
\mathrm{mS} \mathrm{cm}^{-1}\end{array}$ & $\mathrm{pH}$ & Ca mg/100g & $\mathrm{Mg} \mathrm{mg/100g}$ & $\mathrm{K} \mathrm{mg/100g}$ & \multicolumn{2}{|r|}{$\mathrm{PO}_{4} \mathrm{mg} / 100 \mathrm{~g}$} & \multicolumn{2}{|c|}{ Organic Matter \% } \\
\hline Sewage sludge & 7,217 & 7,42 & 25,68 & 7,91 & 397,82 & 59,03 & 963,41 & \multicolumn{2}{|c|}{52,16} \\
\hline Leaves & 3,007 & 5,92 & 64,08 & 62,97 & 687,84 & 0,85 & 104,17 & \multicolumn{2}{|c|}{75,21} \\
\hline Branches & 0,866 & 5,64 & 28 & 7,09 & 30,78 & 0,82 & 16,13 & \multicolumn{2}{|c|}{78,21} \\
\hline Organic Matters & 1,511 & 5,49 & 273,78 & 17,26 & 10,98 & 15,44 & 72,56 & \multicolumn{2}{|c|}{0,01} \\
\hline Inorganic Matters & 1,267 & 7,13 & 35,02 & 6 & 9,58 & 10,58 & 0,76 & \multicolumn{2}{|c|}{65,8} \\
\hline Soil & 2,008 & 7,19 & 16,9 & 0,88 & 1,44 & 0,63 & 0,03 & \multicolumn{2}{|c|}{1,92} \\
\hline W1 (S1) & 4,425 & 7,13 & 120,98 & 45,22 & 291,21 & 39,65 & 16,67 & \multicolumn{2}{|c|}{44,39} \\
\hline W2 (S2) & 2,734 & 7,28 & 69,41 & 26,28 & 259,04 & 48,13 & 8,12 & \multicolumn{2}{|c|}{49,48} \\
\hline W3 (S3) & 4,921 & 6,65 & 96,65 & 13,67 & 9,99 & 15,37 & 1,87 & \multicolumn{2}{|c|}{5,98} \\
\hline W4 (S4) & 1.461 & 6,80 & 26,48 & 2,79 & 1,91 & 15,86 & 0,19 & \multicolumn{2}{|c|}{3,17} \\
\hline Standard* & & $5,5-8,5^{*}$ & $115-350 * *$ & $16-48^{* *}$ & $14-37^{* *}$ & & $0,8-2,5^{* *}$ & & \\
\hline Parameters & $\begin{array}{l}\text { Organic } \\
\text { Carbon\% } \\
\end{array}$ & $\begin{array}{c}\text { Total Nitrogen } \\
\% \\
\end{array}$ & $\begin{array}{c}\text { Organic Nitrogen } \\
\% \\
\end{array}$ & $\begin{array}{c}\mathrm{Fe} \\
\mathrm{mg} \mathrm{kg}^{-1} \\
\end{array}$ & $\begin{array}{c}\mathrm{Mn} \\
\mathrm{mg} \mathrm{kg}^{-1} \\
\end{array}$ & $\begin{array}{c}\mathrm{Zn} \\
\mathrm{mg} \mathrm{kg}^{-1} \\
\end{array}$ & $\begin{array}{c}\mathrm{Cr} \\
\mathrm{mg} \mathrm{kg}^{-1} \\
\end{array}$ & $\begin{array}{c}\mathrm{Pb} \\
\mathrm{mg} \mathrm{kg}^{-1}\end{array}$ & $\begin{array}{c}\mathrm{Cd} \\
\mathrm{mg} \mathrm{kg}^{-1} \\
\end{array}$ \\
\hline Sewage sludge & 30,33 & 5,96 & 2,245 & 3,16 & 0,17 & 0,54 & 0,14 & 0,16 & $<0,01$ \\
\hline Leaves & 43,73 & 2,716 & 2,653 & 2,07 & 0,36 & 1,48 & 0,18 & 0,12 & $<0,01$ \\
\hline Branches & 45,47 & 0,745 & 0,743 & 0,77 & 0,75 & 2,01 & 0,07 & $<0,04$ & $<0,01$ \\
\hline Organic Matters & 62,07 & 1,077 & 1 & 0,67 & 5,83 & 1,45 & 0,08 & 0,14 & $<0,01$ \\
\hline $\begin{array}{c}\text { Inorganic } \\
\text { Matters }\end{array}$ & 38,26 & 2,369 & 2,22 & 3,39 & 0,81 & $<0,15$ & 0,02 & 0,07 & $<0,01$ \\
\hline Soil & 1,12 & 0,113 & 0,103 & $<0,02$ & $<0,01$ & $<0,01$ & $<0,01$ & $<0,01$ & $<0,01$ \\
\hline W1 (S1) & 25,81 & 1,918 & 1,914 & 0,37 & 0,26 & 0,34 & 0,11 & $<0,03$ & $<0,01$ \\
\hline W2 (S2) & 28,77 & 1,693 & 1,69 & 0,67 & 0,04 & 0,36 & 0,08 & $<0,03$ & $<0,01$ \\
\hline W3 (S3) & 3,48 & 0,342 & 0,341 & 0,06 & 0,03 & 0,04 & 0,02 & $<0,01$ & $<0,01$ \\
\hline W4 (S4) & 1,84 & 0,177 & 0,177 & 10,4 & $<0,01$ & $<0,02$ & $<0,01$ & $<0,01$ & $<0,01$ \\
\hline Standard* & & & & $10-30^{*}$ & $450 *$ & $1100^{*}$ & $350 *$ & $150 *$ & $3 *$ \\
\hline
\end{tabular}


Organic matter content of the experimental soil was 0.88 . Increases were also observed in soil organic carbon and total nitrogen contents with the treatments. Increasing contents were observed with increasing treatment doses. Organic carbon contents of S1a, S1b, S2a and S2b treatments were respectively observed as 1.1-1.24-1.48-2.18 and total nitrogen contents were respectively observed as $0.094-0.118-0.097-0.161 \%$. Organic matter content of the experimental soil was 0.52 and total nitrogen content was $0.049 \%$.

With regard to standard values to evaluate soil analyses (FAO, 1990), Mg of samples S1a and S1b was excessive, Ca was sufficient, $\mathrm{K}$ was sufficient in $\mathrm{S} 1 \mathrm{a}$ and excessive in $\mathrm{S} 1 \mathrm{~b}, \mathrm{~N}$ was sufficient in both samples.

Again with regard to standard values used in soil analyses (FAO, 1990), Mg of samples S2a and S2b was excessive, Ca was sufficient, $\mathrm{K}$ was sufficient in $\mathrm{S} 2 \mathrm{a}$ and excessive in $\mathrm{S} 2 \mathrm{~b}, \mathrm{~N}$ was sufficient in both samples. High EC value of sample S3 was because of high EC of natural soil added to mixture to obtain artificial soil from the treatment sludge.

Organic matter content of the sample S5 with chemical fertilizer treatment did not change but phosphorus content slightly increased. Among the exchangeable cations, $\mathrm{Mg}$ was excessive, Ca was sufficient, $\mathrm{K}$ was sufficient and $\mathrm{N}$ was insufficient. Analyses results revealed that sludge-originated products had higher impacts on soil quality than the impacts of chemical fertilizer. $\mathrm{C} / \mathrm{N}$ ratio of entire samples was also within proper limits for soils.

\subsection{Results for Oat}

Effects of different treatments on chemical composition of oat stalks and average values are provided in Table 5. While the effects of treatments on dry matter contents were not found to be significant, effects on NDF were found to be significant at $5 \%$ level and effects on other parameters were found to be significant at $1 \%$ level.

Crude protein ratios varied between 3.50-10.21\% with the lowest value from S3 and the highest value from S4 treatment. The lowest NDF value was observed in S5 treatment with $59.40 \%$ and the highest value was seen in S4 treatment with $70.10 \%$. While the lowest ADF value was obtained from S2a treatment with $33.23 \%$, the highest value was obtained from $S 4$ treatment with $48.15 \%$. Crude fiber ratios varied between $26.55-39.58 \%$ with the lowest value from S4 treatment and the highest value from S1a treatment.

Table 5. Dry matter, crude protein, crude ash, NDF, ADF and crude fiber values of oat stalks

\begin{tabular}{|c|c|c|c|c|c|c|}
\hline Treatments & DM & CP & CA & NDF & ADF & CF \\
\hline S3 & $92,57 \pm 0,03$ & $3,50 \pm 0,01 e$ & $7,29 \pm 0,05 \mathrm{~cd}$ & $60,90 \pm 0,02 b c$ & $34,03 \pm 0,05 \mathrm{de}$ & $36,35 \pm 0,01 \mathrm{e}$ \\
\hline S5 & $92,21 \pm 0,02$ & $3,81 \pm 0,01 \mathrm{e}$ & $8,53 \pm 0,03 b$ & $59,40 \pm 0,02 c$ & $35,82 \pm 0,03 d$ & $38,25 \pm 0,02 d$ \\
\hline S6 & $92,14 \pm 0,01$ & $9,77 \pm 0,01 b$ & $12,68 \pm 0,01 a$ & $64,90 \pm 0,01 b$ & $42,74 \pm 0,01 b$ & $29,80 \pm 0,01 \mathrm{~g}$ \\
\hline S1a & $92,14 \pm 0,05$ & $4,21 \pm 0,01 d$ & $8,37 \pm 0,03 b$ & $60,00 \pm 0,01 b c$ & $34,70 \pm 0,01 \mathrm{de}$ & $39,58 \pm 0,02 a$ \\
\hline $\mathrm{S} 2 \mathrm{a}$ & $92,49 \pm 0,01$ & $4,59 \pm 0,01 d$ & $7,20 \pm 0,06 \mathrm{~cd}$ & $59,50 \pm 0,02 c$ & $33,23 \pm 0,04 \mathbf{e}$ & $39,12 \pm 0,01 b$ \\
\hline $\mathrm{S} 2 \mathrm{~b}$ & $92,60 \pm 0,07$ & $4,47 \pm 0,01 d$ & $6,44 \pm 0,08 d$ & $61,93 \pm 0,03 b c$ & $39,06 \pm 0,01 c$ & $38,67 \pm 0,03 c$ \\
\hline S1b & $92,71 \pm 0,02$ & $5,44 \pm 0,01 c$ & $7,83 \pm 0,02 b c$ & $70,00 \pm 0,02 a$ & $37,70 \pm 0,01 c$ & $33,31 \pm 0,01 f$ \\
\hline S4 & $91,92 \pm 0,01$ & $10,21 \pm 0,01 \mathrm{a}$ & $13,35 \pm 0,01 \mathrm{a}$ & $70,10 \pm 0,01 a$ & $48,15 \pm 0,02 a$ & $26,55 \pm 0,04 h$ \\
\hline sig. & NS & $* *$ & $* *$ & $*$ & $* *$ & $* *$ \\
\hline
\end{tabular}


Table 4. Changes in soil characteristics following the trial

\begin{tabular}{|c|c|c|c|c|c|c|c|c|c|c|c|c|c|c|c|c|}
\hline \multirow{2}{*}{ No } & \multicolumn{4}{|c|}{ Texture } & \multirow{2}{*}{$\mathrm{pH}$} & \multirow{2}{*}{$\begin{array}{c}\text { Org. Mat. } \\
\%\end{array}$} & \multirow{2}{*}{$\begin{array}{c}\text { Phosphorus } \\
\text { ppm P }\end{array}$} & \multirow{2}{*}{ EC } & \multicolumn{4}{|c|}{ Exchangeable Cations $\left(\mathrm{mg} \mathrm{kg}^{-1}\right)$} & \multirow{2}{*}{$\begin{array}{c}\text { ESP* } \\
\% \\
\end{array}$} & \multirow{2}{*}{$\begin{array}{c}\text { Org.C } \\
\% \\
\end{array}$} & \multirow{2}{*}{$\begin{array}{l}\mathrm{N} \\
\%\end{array}$} & \multirow[t]{2}{*}{$\mathrm{C} / \mathrm{N}$} \\
\hline & \%Clay & \%Silt & \%Sand & Class & & & & & Mg & $\mathrm{Ca}$ & $\mathrm{Na}$ & $\mathbf{K}$ & & & & \\
\hline S1a & 21,42 & 20,18 & 58,40 & Sandy clay loam & 7,4 & 1,88 & 66,35 & 0,371 & 707 & 3152 & 256 & 328 & 4,72 & 1,11 & 0,094 & 11,81 \\
\hline S1b & 21,42 & 24,34 & 54,24 & Sandy clay loam & 7,3 & 2,10 & 83,14 & 0,392 & 703 & 3534 & 258 & 464 & 4,34 & 1,24 & 0,118 & 10,52 \\
\hline S2a & 21,42 & 28,50 & 50,08 & Sandy clay loam & 7,5 & 2,51 & 77,98 & 0,395 & 625 & 3174 & 322 & 304 & 6,02 & 1,48 & 0,097 & 15,31 \\
\hline S2b & 23,10 & 22,26 & 54,64 & Sandy clay loam & 7,7 & 3,71 & 91,87 & 0,368 & 629 & 3308 & 272 & 556 & 4,85 & 2,18 & 0,161 & 13,54 \\
\hline S3 & 4,78 & 57,62 & 37,60 & Sandy clay loam & 7,4 & 3,08 & -- & 1,710 & 1354 & 2846 & 400 & 640 & 6,02 & 1,81 & 0,171 & 10,59 \\
\hline S4 & 35,98 & 32,66 & 31,36 & Clay loam & 7,3 & 3,06 & -- & 2,210 & 1262 & 3002 & 410 & 588 & 6,19 & 1,80 & 0,174 & 10,35 \\
\hline S5 & 25,58 & 26,42 & 48,00 & Sandy clay loam & 8,0 & 0,86 & 25,10 & 0,374 & 662 & 3010 & 188 & 176 & 3,74 & 0,51 & 0,041 & 12,52 \\
\hline S6 & 21,42 & 20,18 & 58,40 & Sandy clay loam & 7,8 & 0,88 & 17,60 & 0,291 & 755 & 2856 & 262 & 164 & 5,15 & 0,52 & 0,049 & 10,56 \\
\hline
\end{tabular}

* Exchangeable sodium percentage

S1a: natural soil + 500 g S1 $\quad$ S1b: natural soil + 750 g S1 $\quad$ S2a: natural soil + 500 g S2 $\quad$ S2b: natural soil + 750 g S2

S3: all samples S3 S4: all samples S4 S5: natural sail + fertilizer $\left(\mathrm{N}_{8} \mathrm{P}_{6}\right) \quad$ S6: Control soil (without any supplementation) 
Effects of different treatments on chemical composition of oat kernels and average values are provided in Table 6. Effects of treatments on all of the investigated parameters were found to be significant at $1 \%$ level.

Dry matter contents of oat kernels varied between $92.86-93.64 \%$ with the lowest value in S1b and the highest value in S5 treatment. Crude protein ratios varied between $6.31-16.73 \%$ with the lowest value from S2a and the highest value from S4 treatment. The lowest crude ash content was observed in S3 treatment with $3.84 \%$ and the highest crude ash content was observed in S6 treatment with $59.68 \%$. The lowest crude fiber content was obtained from S1a treatment with $19.71 \%$ and the highest value was obtained from S1b treatment with $28.29 \%$.

Table 6. Dry matter, crude protein, crude ash and crude fiber values of oat kernels

\begin{tabular}{|c|c|c|c|c|}
\hline Treatments & DM & CP & CA & CF \\
\hline S3 & $92,88 \pm 0,01 b$ & $7,55 \pm 0,01 \mathrm{~cd}$ & $3,84 \pm 0,03 g$ & $23,61 \pm 0,01 c$ \\
\hline S5 & $93,64 \pm 0,01 a$ & $7,70 \pm 0,02 c$ & $4,55 \pm 0,03 f$ & $24,37 \pm 0,01 b$ \\
\hline S6 & $92,38 \pm 0,02 c$ & $13,09 \pm 0,03 b$ & $9,68 \pm 0,02 a$ & $21,61 \pm 0,02 d$ \\
\hline S1a & $91,48 \pm 0,03 d$ & $6,82 \pm 0,03 \mathrm{~cd}$ & $5,44 \pm 0,05 c d$ & $19,71 \pm 0,03 \mathrm{~g}$ \\
\hline $\mathrm{S} 2 \mathrm{a}$ & $91,41 \pm 0,02 d$ & $6,31 \pm 0,05 d$ & $5,19 \pm 0,04 \mathrm{de}$ & $23,70 \pm 0,02 c$ \\
\hline $\mathrm{S} 2 \mathrm{~b}$ & $91,12 \pm 0,03 \mathrm{de}$ & $6,76 \pm 0,03 c d$ & $4,64 \pm 0,03 \mathrm{ef}$ & $21,27 \pm 0,03 e$ \\
\hline S1b & $92,86 \pm 0,03 e$ & $7,95 \pm 0,02 c$ & $5,79 \pm 0,01 c$ & $28,29 \pm 0,01 a$ \\
\hline S4 & $91,12 \pm 0,03 \mathrm{de}$ & $16,73 \pm 0,02 a$ & $8,23 \pm 0,01 b$ & $20,54 \pm 0,04 \mathrm{~g}$ \\
\hline sig. & $* *$ & $* *$ & $* *$ & $* *$ \\
\hline
\end{tabular}

DM: Dry Matter, CP: Crude Protein, CA: Crude Ash, CF: Crude Fiber

Effects of different treatments on morphological characteristics of oat plant and average values are provided in Table 7. Effects of treatments on entire characteristics were found to be significant at $1 \%$ level.

Plant heights varied between $63.00-80.00 \mathrm{~cm}$ with the lowest value in $\mathrm{S} 5$ treatment and the highest value in S1b treatment. The lowest kernel yield was observed in S5 treatment with $0.53 \mathrm{~g}$ and the highest kernel yield was obtained from S1b treatment with $0.78 \mathrm{~g}$. While the lowest harvest index was obtained from S3 treatment with $21.76 \%$, the highest value was observed in S5 treatment with $28.30 \%$.

Table 7. Morphological characteristics of oat plants

\begin{tabular}{|c|c|c|c|}
\hline Treatments & Plant height $(\mathrm{cm})$ & Grain Yield (g) & Harvest Index (\%) \\
\hline S1a & $69,33 \pm 3,1 \mathrm{~cd}$ & $0,59 \pm 3,0 \mathrm{~b}$ & $22,00 \pm 1,4 \mathrm{bc}$ \\
\hline S1b & $80,00 \pm 2,0$ a & $0,78 \pm 2,1 \mathrm{a}$ & $22,42 \pm 1,3 \mathrm{bc}$ \\
\hline S2a & $70,67 \pm 3,2 \mathrm{bc}$ & $0,65 \pm 3,0 \mathrm{~b}$ & $28,27 \pm 2,0 \mathrm{a}$ \\
\hline$S 2 b$ & $72,33 \pm 2,8 b$ & $0,62 \pm 3,0 \mathrm{~b}$ & $28,30 \pm 1,1$ a \\
\hline S3 & $71,67 \pm 2,0 \mathrm{bc}$ & $0,72 \pm 2,0 a$ & $21,76 \pm 0,7 \mathrm{c}$ \\
\hline S4 & $66,67 \pm 2,6 \mathrm{~d}$ & $0,77 \pm 2,4$ a & $26,86 \pm 1,0$ a \\
\hline S5 & $63,00 \pm 3,5$ e & $0,53 \pm 2,4 c$ & $23,56 \pm 1,8 \mathrm{~b}$ \\
\hline S6 & $66,67 \pm 1,5 \mathrm{~d}$ & $0,60 \pm 2,1 b$ & $27,75 \pm 0,6$ a \\
\hline sig. & $* *$ & $* *$ & $* *$ \\
\hline
\end{tabular}

\subsection{Results for Turf Grass}

Effects of different treatments on chemical composition of turf grass and average values are provided in Table 8. While the effects of treatments on crude ash were significant at $5 \%$ level, effects of treatments on the other characteristics were significant at $1 \%$ level.

Dry matter ratios varied between $13.26-16.63 \%$ with the lowest value in sample S3 and the highest in sample S2a. While the lowest crude protein ratio was obtained from sample S6 with $14.14 \%$, the highest value was seen in sample S3 with $21.50 \%$. Crude ash ratios varied between $12.29-14.11 \%$ with the lowest 
value in sample S2a and the highest value in sample S4. NDF ratios of turf grass varied between 42.61$50.34 \%$ with the lowest value in treatment S2b and the highest value in treatment S1b. While the lowest ADF ratio was observed in S6 treatment with $24.84 \%$, the highest value was seen in S2b treatment with $34.03 \%$.

Table 8. Dry matter, crude protein, crude ash, ADF and NDF values of turf grass

\begin{tabular}{cccccc}
\hline Treatments & DM & CP & CA & NDF & ADF \\
\hline S3 & $13.26 \pm 0,01 \mathrm{c}$ & $21.50 \pm 0,02 \mathrm{a}$ & $14.01 \pm 0,03 \mathrm{a}$ & $49.03 \pm 0,02 \mathrm{a}$ & $30.73 \pm 0,02 \mathrm{~b}$ \\
S5 & $13.94 \pm 0,03 \mathrm{bc}$ & $17.91 \pm 0,03 \mathrm{~b}$ & $13.83 \pm 0,03 \mathrm{a}$ & $45.49 \pm 0,03 \mathrm{c}$ & $30.99 \pm 0,02 \mathrm{~b}$ \\
S6 & $16.52 \pm 0,01 \mathrm{a}$ & $14.14 \pm 0,04 \mathrm{e}$ & $12.29 \pm 0,03 \mathrm{~b}$ & $46.97 \pm 0,03 \mathrm{bc}$ & $24.84 \pm 0,03 \mathrm{~b}$ \\
S1a & $14.52 \pm 0,01 \mathrm{bc}$ & $15.63 \pm 0,03 \mathrm{~cd}$ & $13.30 \pm 0,03 \mathrm{ab}$ & $46.47 \pm 0,03 \mathrm{c}$ & $34.03 \pm 0,02 \mathrm{a}$ \\
S2a & $16.63 \pm 0,01 \mathrm{a}$ & $17.20 \pm 0,02 \mathrm{~b}$ & $12.44 \pm 0,03 \mathrm{~b}$ & $47.42 \pm 0,03 \mathrm{bc}$ & $27.61 \pm 0,05 \mathrm{c}$ \\
S2b & $15.43 \pm 0,03 \mathrm{ab}$ & $16.27 \pm 0,03 \mathrm{c}$ & $13.94 \pm 0,03 \mathrm{a}$ & $42.61 \pm 0,05 \mathrm{~d}$ & $34.13 \pm 0,01 \mathrm{a}$ \\
S1b & $16.34 \pm 0,01 \mathrm{a}$ & $15.22 \pm 0,05 \mathrm{~d}$ & $13.80 \pm 0,03 \mathrm{a}$ & $50.34 \pm 0,01 \mathrm{a}$ & $30.76 \pm 0,03 \mathrm{~b}$ \\
S4 & $13.57 \pm 0,03 \mathrm{bc}$ & $14.80 \pm 0,03 \mathrm{de}$ & $14.11 \pm 0,03 \mathrm{a}$ & $47.06 \pm 0,02 \mathrm{bc}$ & $34.22 \pm 0,02 \mathrm{a}$ \\
\hline sig. & $* *$ & $* *$ & $*$ & $* *$ & $* *$ \\
\hline
\end{tabular}

${ }^{*} \mathrm{p} \leq 0.05 ;{ }^{*} \mathrm{p} \leq 0.01 ; \mathrm{NS}$ : non-significant

DM: Dry Matter, CP: Crude Protein, CA: Crude Ash, NDF: Neutral Deterjant Fiber, ADF: Acid Deterjant Fiber

Differences in dry matter and protein ratios of species were mainly due to genetic differences among them and such values varied also based on leaf, stem and spike ratios, ripening periods, temperature and fertilization regimes (Ball et al., 2001). Genç Lermi (2009) indicated that combined effect of nitrogen and phosphorus increased crude protein ratios. Cox et al., (1993); Sarker (2000) reported increased crude protein ratios with nitrogenous fertilizers. Organic matter and nitrogen of artificial soils of the present study reflected in crude protein ratios of the treatments S3 and S4. Excessive nitrogen and organic matter of the treatment 3 also reflected in results of chemical analyses. Crude protein findings of the current study were similar to ones reported by Boudon and Peyraud, (2001); Lee et al., (2001); Chaves et al., (2006); Taweel et al., (2005) and were higher than the ones reported by Lovet et al., (2005).

Genç Lermi (2009) reported increasing NDF ratios with increasing nitrogen treatments and decreasing ratios with increasing phosphorus treatments. Again, Genç Lermi, (2009) indicated insignificant effects of phosphorus treatments on ADF ratios but increasing ratios with nitrogen treatments. Yolcu et al., (2010) carried out a two-year study and reported insignificant effects of treatments on ADF and NDF ratios during the first year but significant effects during the second year of the study. Adeli et al. (2005) reported increasing ADF and decreasing NDF ratios of Bermuda grass with waste material treatments. Increased fiber ratios also affect dry matter contents. ADF and NDF values of the present study were similar to ones reported by Boudon and Peyraud, (2001); Chaves et al., (2006); Lee et al., (2001) and were higher than the ones reported by Lovet et al., (2005) and Lee et al., (2009). Differences with the results of others were mainly due to the characteristics of composts used in present study. Dry matter ratios of the current study were lower than the ones indicated by Lovet et al., (2005) and Miller et al., (2001) and crude ash ratios were higher than the ones reported by Boudon and Peyraud, (2001) and Lovet et al., (2005). Again such differences were mostly because of chemical characteristics and mineral content of the compost used in the present study.

Significant increases were observed in protein contents of both the stalks and kernels of oat with the effective use on nitrogen in S4 treatment. Rich phosphorus, nitrogen and other mineral contents of the treatments effected chemical composition in different fashions. While the treatments were increasing protein contents in S4 treatments, they decreased the crude fibers. Additionally, ADF and NDF ratios also increased with treatments.

Kernel protein contents were similar to the some values observed by Kahraman et al., (2012) and were lower than some other values. Harvest index values of the present study were similar to the values reported by Luby and Stuthman, (1983); Sinclair, (1998) and Takeda and Frey, (1976). Kernel yield values 
were also similar to values obtained by Luby and Stuthman, (1983) and Takeda and Frey, (1976). While plants heights of the present study were similar to ones reported by Luby and Stuthman, (1983), they were lower than the values indicated by Kahraman et al., (2012). Such differences were mainly because of cultivar characteristics.

\section{Conclusions}

Mixture of sewage sludge with leaves, tree branches and organic and inorganic trash of the aerated sand trap has been provided and recycling has been realised by transformation of the sludge into a new utilizable product within the context of this study. Not only an utilizable final product has been obtained but also a significant alternative has been set forth with this product obtained from the sewage sludge. Not only recycling of the sludge but also its appropriate disposal and other wastes' recycling is also realised with the product obtained by composting the sewage sludge.

One of the basic objective of the present study was to investigate the effects of different sludge composts on soil characteristics and plant yields of oat and grass. Results revealed that sludge composts were more effective on soil and plant yields than the chemical fertilizer. Also, sludge composts were more effective on yield of oat plants than the yield of grass. Increasing compost doses resulted in increasing impacts on soil and plant yield.

\section{Acknowledgement}

This study and investigation has been endorsed by the Cumhuriyet University CÜBAP Chairmanship with Project No M 465 and Project No M 384. I sincerely thank CÜBAP Chairmanship for their endorsement.

\section{References}

Adeli A., Varco J.J., Sistani K.R. and Rowe D.E. (2005), Effects of swine lagoon effluent relative to commercial fertilizer applications on warm-season forage nutritive value, Agronomy Journal, 97, 408-417.

Aggelides S.M. and Londra P.A. (2000), Effects of Compost Produced from Town Wastes and Sewage Sludge on the Physical Properties of a Loamy and a Clay Soil, Bioresource Technology, 71, 253-259.

Antolín M.C., Pascual I., García C., Polo A. and Sánchez-Díaz M. (2005), Growth, Yield and Solute Content of Barley in Soils Treated With Sewage Sludge Under Semiarid Mediterranean Conditions, Field Crops Research, 94, 224237.

Ball D.M., Collins M., Lacefield G.D., Martin N.P., Mertens D.A, Olson K.E., Putnam D.H., Undersander D.J. and Wolf M.W. (2001), Understanding forage quality. American Farm Bureau Federation Publication 1-01, Park Ridge, IL.

Boudon A. and Peyraud J.L. (2001), The release of intracellular constituents from fresh ryegrass (Lolium perenne L.) during ingestive mastication in dairy cows: effect of intracellular constituent, season and stage of maturity, Animal Feed Science and Technology, 93, 229-245.

Bousselhaj K., Fars S., Laghmari A., Nejmeddine A., Ouazzani N. and Ciavatta C. (2004), Nitrogen fertilizer value of sewage sludge cocomposts, Agronomie, 24, 487-492.

Chavesa A.V., Waghorn G.C., Brookes I.M. and Woodfield D.R. (2006), Effect of maturation and initial harvest dates on the nutritive characteristics of ryegrass Lolium perenne L., Animal Feed Science and Technology, 127, 293-318.

Chen Y. (2012), Sewage Sludge Aerobic Composting Technology Research Progress, AASRI Procedia, 1, 339 - 343.

Compost rescript, 2015. Official Gazette, 5 March 2015 No:29286

Cox W.J., Kalonge S., Cherney D.J.R. and Reid W.S. (1993), Growth, yield and quality of forage maize under different nitrogen management practices, Agronomie, 85, 843-347.

Eftoda G. and Mc Cartney D. (2004), Determining the critical bulking agent requirement for municipal biosolids composting, Compost science \& utilization, 12, 208-218. 
El Fels L., Zamama M., El Asli A. And Hafidi M. (2014), Assessment of biotransformation of organic matter during cocomposting of sewage sludge-lignocelullosic waste by chemical FTIR analyses and phytotoxicity tests, Int Biodeter Biodegr., 87,128-137.

El Fels L., El Ouaqoudia F.Z., Lemeeb L., Geffroy C., Ambles A. and Hafidi M. 2016(a), Occurrence of plant and fecal steroid and their evolution during co-composting of sewage sludge and lignocellulosic waste, Biochemical Engineering Journal, 105, 497-504.

El Fels L., Hafidi M. and Ouhdouch Y. 2016(b), Date palm and the activated sludge co-composting actinobacteria sanitization potential, Environmental Technology, 37(1), 129-135.

FAO. 1990. Micronutrient. Assessment at the country leaves an international study. FAO Soils Bulletion 63. Rome.

Genç Lermi A. 2009. The effects of nitrogen and phosphor fertilizers on hay yield, hay quality and botanical composition of forest grassland in Bartın. Ph.D. Thesis. Ankara University Graduate School of Natural and Applied Sciences Department of Agronomy.

Gouxue L., Zhang F., Sun Y., Wong J.W.C. and Fang M. (2001), Chemical evaluation of sewage sludge composting as a mature indicator for composting process, Water, Air, Soil Pollution, 132, 333-345.

Hernandez T., Moral R., Perez-Espinosa A., Moreno-Caselles J., Perez-Murcia M.D. and Garcia C. (2002), Nitrogen Mineralisation Potential in Calcareous Soils Amended with Sewage Sludge, Bioresource Technology, 83, 213-219.

Kahraman T., Avci R., Öztürk I. And Tülek A. (2012), Thrace - Determination of Proper oat genotypes in the Marmara region, Research Journal of Agricultural Science, 5(2), 24-28.

Khalil A I., Hassouna M.S. and El-Ashqar H.M.A. (2011), Changes in physical, chemical and microbial parameters during the composting of municipal sewage sludge, World J Microbiol Biotechnol, 27, 2359-2369.

Kulikowska D. and Klimiuk E. (2011), Organic matter transformations and kinetics during sewage sludge composting in a two-stage system, Bioresource Technology, 102, 10951-10958.

Larson W.E., Susag R.H., Dowdy R.H., Clappa C.E. and Larson R.E. (1974), Use of Sewage Sludge in Agriculture with Adequate Environmental Safeguards, Sludge Handling and Disposal Seminar Proceedings, 27-46, Toronto.

Lee M.R.F., Jones E.L., Moorby J.M., Humphreys M.O., Theodorou M.K., Macrae J.C. and Scollan N.D. (2001), Production responses from lambs grazedon Lolium perenne selected for an elevated water-soluble carbohydrate concentration, Animal Research, 50, 441-449.

Lee J.M., Donaghy D.J., Sathish P. and Roche J.R. (2009), Interaction between water-soluble carbohydrate reserves and defoliation severity on the regrowth of perennial ryegrass (Lolium perenne L.)-dominant swards, Grass and Forage Science, 64, 266-275.

Lovett D.K. McGilloway D. Bortolozzo A. Hawkins M. Callan J. Flynn B. O'Mara F.P. 2005. In vitro fermentation patterns and methane production as influenced by cultivar and season of harvest of Lolium perenne L., Grass and Forage Science 61, 9-21.

Luby J.J. and Stuthman D.D. (1983), Evaluation of Avena sativa L./A. fatua L. Progenies for Agronomic and Grain Quality Characters, Crops Science, 23, 1047-1052.

Miller L.A., Moorby J.M., Davies D.R., Humphreys M.O., Scollan N., MacRae J.C. and Theodorou M.K. (2001), Increased concentration of water-soluble carbohydrate in perennial ryegrass (Lolium perenne L: milk production from late-lactation dairy cows, Grass and Forage Science, 56, 383-394.

Pascual I., Antolín M.C., García C., Polo A. and Sánchez-Díaz M. (2005), Effect of Water Defcit on Microbial Characteristics in Soil Amended with Sewage Sludge or Inorganic Fertilizer Under Laboratory Conditions, Bioresource Technology, 98, 29-37.

Santamaría-Romero S. and Ferrera R. (2001), Dynamics and relationships among microorganisms, organic-C and total-N during composting and vermicomposting, Agrociencia, 35, 377-383.

Sarker V. (2000), Effect of different doses of nitrogen fertilizer on growth, yield, chemical composition and degradability of Zamboo grass (Hybrid jowar). MS Thesis, Department of Animal Nutrition, Bangladesh Agricultural University, Mymensingh, Bangladesh.

Sinclair T.R. (1998), Historical Changes in Harvest Index and Crop Nitrogen Accumulation, Crop Science, 38, 638-64.

Takeda K. and Frey K.J. (1976), Contributions of Vegetative Growth Rate and Harvest Index to Grain Yield of Progenies from Arena sativa X A. sterilis Crosses, Crop Science, 16, 817-821. 
Tang J. and Katayama A. (2005), Relating quinine profile to the aerobic biodegradation in thermophilic composting processes of cattle manure with various bulking agents, World J. Microbiol. Biotechnol., 21, 1249-1254.

Taweel H.Z., Tas B.M., Smit H.J., Elgersm A., Dijkstra J. and Tamminga S. (2005), Improving the quality of perennial ryegrass (Lolium perenne L.) for dairy cows by selecting for fast clearing and/or degradable neutral detergent fiber, Livestock Production Science, 96, 239 - 248.

Tweib S.A.K., Abdul Rahman R., Khalil M.S. (2014), Physicochemical Changes in Co-Composting Process of Palm Oil Mill Sludge (POMS) and Solid Waste (Kitchen Waste) Using Bin Composter, Arab J Sci Eng., 39, 2455-2462.

Willson G.B., Parr J.F., Epstein E., Marsh P.B., Chaney R.L., Colacicco D., Burge W.D., Sikora L.J., Tester C.F. and Hornick S. (1980), Manual for composting sewage sludge by the Beltsville aerated-pile method. EPA-600/8-80-022, USA.

Yolcu H., Gunes A., Dasci M., Turan M. and Serin Y. (2010), The effects of solid, liquid and combined cattle manure applications on the yield, quality and mineral contents of common vetch and barley intercropping mixture, Ekoloji, 19(75), 71-81.

Zhou H.B., Maa C., Gao D., Chen T.B., Di Zheng G., Chen J. And Pan T.H. (2014), Application of a recyclable plastic bulking agent for sewage sludge composting, Bioresource Technology, 152, 329-336.

Zuokaitè E. And Zigmontienè A. (2013), Application of a Natural Cover during Sewage Sludge Composting to Reduce Gaseous Emissions, Pol. J. Environ. Stud., 22(2), 621-626. 